\title{
In Fed Watchers' Eyes: Hawks, Doves and Monetary Policy
}

\author{
Klodiana Istrefi ${ }^{1,2}$
}

July 2018, WP \#725

\begin{abstract}
I construct a novel measure of policy preferences of the Federal Open Market Committee (FOMC) as perceived in public. This measure is based on newspaper and financial media coverage of 130 FOMC members serving during 1960-2015. Narratives reveal that about 70 percent of these FOMC members are perceived to have had persistent policy preferences over time, as either inflation-fighting hawks or growth-promoting doves. The rest are perceived as swingers, switching between types, or remained an unknown quantity to markets. Hawk and Dove perceptions capture "true" tendencies as expressed in preferred rates, forecasts and dissents of these FOMC members well. At the FOMC level the composition of hawks and doves varies significantly, featuring slow- and fast-switching hawkish and dovish regimes, due to the rotation of voting rights each year, members' turnover and swings in preferences.
\end{abstract}

Keywords: Monetary Policy, Federal Reserve, FOMC, Policy Preferences, Inflation JEL classification: E43, E47, E63, G12

\footnotetext{
${ }^{1}$ Banque de France, klodiana.isterfi@,banque-france.fr

Working Papers reflect the opinions of the authors and do not necessarily express the views of the Banque de France. This document is available on publications.banque-france.fr/en
} 


\section{NON-TECHNICAL SUMMARY}

Commentators on monetary policy and market participants often refer to central bankers with labels hawk and dove, where a hawk is thought of assigning a higher priority to fighting inflation and a dove to supporting more output growth and employment. This paper quantifies these perceptions about the FOMC, the monetary policy decision-making body in the US. In a first step, a measure of perceived policy preferences of the FOMC, expressed in a hawk-dove scale, based on newspaper and financial media coverage, is presented. In a second step, perceptions are matched with "true" tendencies as expressed in FOMC transcripts, with votes and forecasts, not available to the public in real time.

Hawk or Dove type is quantified at the individual level for 130 FOMC members serving during 1960 to 2015. The period under investigation comprises the FOMC under seven Federal Reserve chairpersons, from William McChesney Martin to Janet Yellen. Perception on the type is based on the quantification of narratives in newspaper articles, financial media outlets and business reports of Fed watchers in the US with regard to policy leanings of each FOMC member with respect to inflation and economic growth (employment). To this aim, about 20,000 articles or reports from more than 30 newspapers and business reports of Fed watchers with reference to FOMC members are read (human reading).

This paper quantifies as hawk or dove about 93 percent of 130 FOMC members that served during 1960 to 2015. When observing the evolution of perceptions over time for each member, it shows that about 70 percent were perceived as all-time hawks or doves and 24 percent as swinging camps. The rest remained unknown. At the FOMC level, the hawk and dove composition of the FOMC varied substantially during 1960-2015, featuring hawkish and dovish majorities. The variation in the hawk-dove measure is due to the annual rotation of the four Reserve Bank presidents, to members' turnover and in specific periods, to swingers, describing FOMC members whose preferences are perceived as switching over time. Large swings in preferences are observed in relation the state of the economy but also in relation to intensified discussions on price stability and inflation targets in the early 1990s and following Greenspan's view on productivity and inflation in the late 1990s. Within the FOMC, the Reserve Bank Presidents are perceived as hawkish while the Board of Governors is perceived to switch often to dovish or hawkish majority.

To investigate whether hawk and dove perceptions capture "true" tendencies, they are compared with actions (preferred rates, votes, forecasts) of each FOMC member over time, whenever available. Overall there is a strong match between perceptions and actions: (i) majority of hawkish (dovish) preferred rates belong to perceived hawks (doves), (ii) dissents for tighter policy are predominantly cast from perceived hawks and dissents for ease are cast from perceived doves, and (iii) perceived hawks tend to forecast on average a higher inflation than doves.

Overall, this paper builds a hawk-dove measure for the FOMC and it shows that it is informative of individual FOMC member's actions and the dynamics of the FOMC, not observed in real time. This measure can be used for several research purposes, i.e., to investigate questions that relate to market perceptions on who is in majority, the hawks, the doves or a balance, with market expectations on future path of monetary policy or inflation expectations or to learn about monetary policy shocks given exogenous changes in the composition of the preferences due to the rotation of voting rights of Reserve Bank presidents, among other interesting questions. 

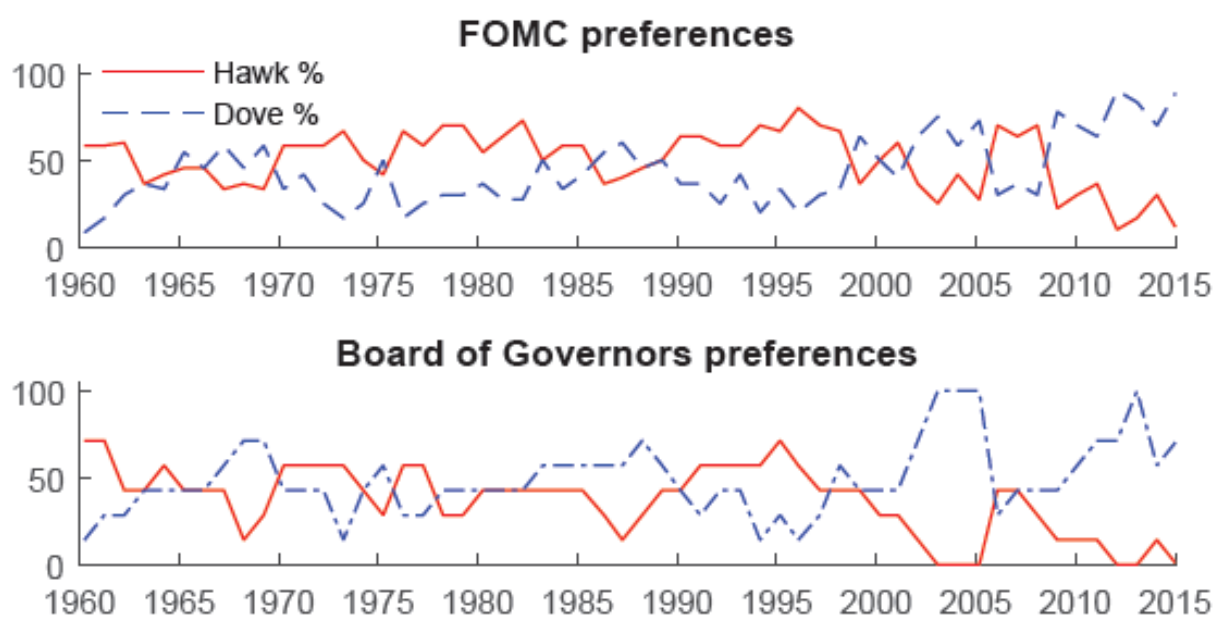

Regional Fed Presidents preferences

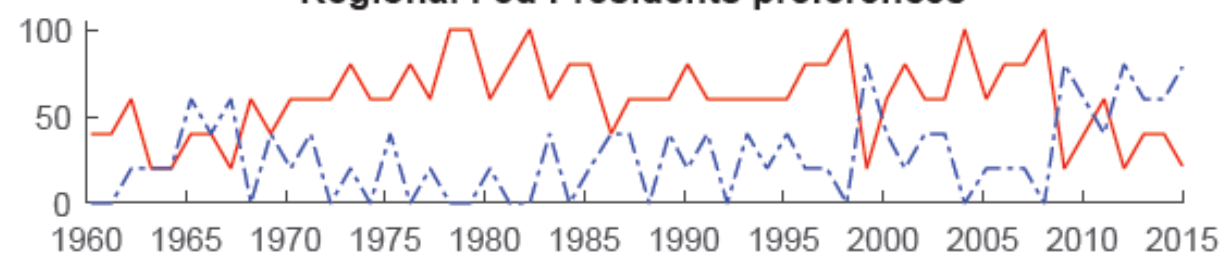

Notes: The share of perceived hawks and doves for each FOMC (beginning of year), from 1960 to 2015. In the chart, the share does not always add up to 100, as it can be that the policy preference of one or more members is not known yet. Source: Istrefi (2017).

\section{Les «faucons», les «colombes» et la politique monétaire aux États Unis}

\section{RÉSUMÉ}

Les archives de journaux américains révèlent qu'environ 70\% des membres du FOMC, en poste durant la période 1960-2015, sont perçus comme ayant des préférences persistantes en matières de politiques monétaires, que ce soit des faucons qui combattent l'inflation ou des colombes qui favorisent la croissance. Le reste bascule d'un camp à un autre au fil du temps. Cette mesure est basée sur la couverture par les journaux et les médias financiers de 130 membres du FOMC siégeant au cours de la période 1960-2015. Les perceptions de «faucons» et « colombes» reflètent bien les "vraies" tendances telles qu'exprimées dans les taux préférentiels, les prévisions et les votes de ces membres du FOMC.

Mots-clés : Comité de Politique Monétaire; Reserve Fédérale Américaine; Préférences; Inflation

Les Documents de travail reflètent les idées personnelles de leurs auteurs et n'expriment pas nécessairement la position de la Banque de France. Ils sont disponibles sur publications.banque-france.fr 


\title{
In Fed Watchers' Eyes: Hawks, Doves and Monetary Policy*
}

\author{
Klodiana Istrefi \\ Banque de France
}

July 2019

\begin{abstract}
I construct a novel measure of policy preferences of the Federal Open Market Committee (FOMC) as perceived in public. This measure is based on newspaper and financial media coverage of 130 FOMC members serving during 1960-2015. Narratives reveal that about 70 percent of these FOMC members are perceived to have had persistent policy preferences over time, as either inflation-fighting hawks or growth-promoting doves. The rest are perceived as swingers, switching between types, or remained an unknown quantity to markets. Hawk and Dove perceptions capture "true" tendencies as expressed in preferred rates, forecasts and dissents of these FOMC members well. At the FOMC level the composition of hawks and doves varies significantly, featuring slow- and fast-switching hawkish and dovish regimes, due to the rotation of voting rights each year, members' turnover and swings in preferences.
\end{abstract}

JEL codes: E43, E47, E63, G12.

Keywords: monetary policy, Federal Reserve, FOMC, policy preferences, inflation.

*The views expressed in this paper are those of the author and do not necessarily reflect those of the Banque de France or the Eurosystem. I would like to thank particularly Michael McMahon and Arsenios Scaperdas for their helpful discussions of this work. In addition I am grateful to Philippe Andrade, Michael Bordo, Bill English, Jordi Gali, Robert L. Hetzel, Narayana Kocherlakota, Thomas Laubach, Leonardo Melosi, Julien Matheron, David Papell, Ricardo Reis, Eugene White, Mirko Wiederholt, Volker Wieland and seminar and conference participants at Rutgers University, Geneva Institute, T2M 2017, Hamburg University, EEA 2017, Vienna Macro Workshop, ICMAIF 2018, IIAE 2018, Conference on Advances in Applied Macro-Finance, 4th OXFORDNY Fed Monetary Economics Conference, OFCE, and at the Federal Reserve of St. Louis for discussions and comments. I thank Anais Galdin for her excellent research assistance. 


\section{Introduction}

Contrary to the assumption of theoretical models, market participants have long learned that monetary policy is not decided by a single individual maximizing a well-defined preference. ${ }^{1,2}$ For instance, private sector and Fed watchers, devote a lot of time (and money) to infer the economic beliefs and the policy preference of the FOMC with the aim to predict future policy path. They recognize that policy decisions selected by a committee are a product of members' policy choices and preferences and that these preferences differ. Therefore, personal background, political affiliation, public statements and voting records of all policy makers who participate in committee discussions are closely monitored for clues to the likely course of policy. ${ }^{3}$ Although there have been attempts in the literature to learn ex post about central bankers' true preferences (through Taylor rules or votes), almost nothing is known on how markets have perceived these preferences either in real time or ex post. ${ }^{4}$ This is important as, eventually, market participants' decisions depend on their perceptions of who they think the policymaker is and what consequences that has for policy. For instance, it is the uncertainty of the public over the policymaker's type that allows for meaningful notions of central banker's reputation and learning studied in the seminal works of Backus and Driffill (1985) and Barro (1986).

To fill this gap, in a first step I develop a measure of perceived policy preferences of the FOMC based on newspaper and financial media coverage. The measure is expressed in a hawk-dove scale, where hawks are those members believed to put the inflation fight above other goals and doves those seen as pro-growth and more tolerant to price pressures, or the threat of them. In a second step, I ask whether these perceptions capture "true" tendencies as expressed in narratives in FOMC transcripts, with contemporaneous FOMC votes and FOMC forecasts, not available to the public in real time, when perceptions are formed. Hawk or Dove is quantified at the individual level for 130 FOMC members serving between 1960 to 2015.

\footnotetext{
1 "My experience as a member of the FOMC left me with a strong feeling that the theoretical fiction that monetary policy is made by a single individual maximizing a well-defined preference function misses something important." (Blinder 1998)

${ }^{2}$ Theoretical models on central bank design and monetary policy committees are on the rise, see among others Riboni and Ruge-Murcia (2010) for issues of agenda-setting and Sibert (2003) and Hansen and McMahon (2016) on models of reputation-building on monetary policy committees.

${ }^{3}$ In revising the lessons from history in choosing a Fed chair, Romer and Romer (2004) also suggested that one can learn about the economic beliefs of these people by looking at certain background characteristics (like education, job experience and political partisanship) and narrative records of their economic beliefs, as expressed in their writings and speeches before joining the Fed.

${ }^{4}$ Recently, Hamilton et al. (2011) provide estimates of ex post market's perceived monetary policy rule for the Federal Reserve, for the period 1994 and 2007.
} 
Perception on the type is based on the quantification of narratives in newspaper articles, financial media outlets and business reports of Fed watchers in the US with regard to policy leanings of each FOMC member with respect to inflation and economic growth (employment). About 20,000 articles or reports from more than 30 newspapers and business reports of Fed watchers with reference to FOMC members are read. ${ }^{5}$

The narrative record in the media is used as a public source and a filter of all relevant information to guess the central banker's type. This includes information with regard to members personal background, political interests, political supporters, expressed economic beliefs before joining and during their time at the Federal Reserve and policy actions (votes and dissents). I summarize the perceptions of policy preferences in a hawk or dove scale, however its measurement takes into account that labels have been different over time (i.e. conservative, liberal, easy money guy, tight money guy, inflation dove or inflation hawk, among others). In addition, Hawk and Dove perceptions have been informed whenever FOMC members are cited about their positions with respect to the actual or future inflation and economic growth (unemployment, recession risks) or their preferred direction of policy.

The hawk-dove measure quantifies real time perceptions as expressed in media, at the frequency of the FOMC meetings, based on information prior to the meeting. The measure has a cross-sectional and a time series dimension. Overtime, for each member, the perception is based on a common definition, that is the policy leaning with respect to the dual mandate of the Federal Reserve: maximum employment and stable prices. Sometimes the observation is done with respect to the preferred direction of the monetary policy instrument (i.e. money growth, interest rates, or other unconventional tools). As such, within an FOMC, for the same objective and same economic conditions, some members are perceived to be on the hawkish side and some on the dovish side, i.e. some worrying about inflation while others about the possibility of a recession. The time dimension captures changes in the composition of hawks and doves at the FOMC due to several factors: the annual rotation scheme of voting rights of Reserve Bank presidents, the turnover of members and swings in preferences.

I quantified as hawk or dove about 93 percent of 130 FOMC members that served during 1960 to 2015. When observing the evolution of perceptions over time for each member, I find that 39 percent were perceived as all-time hawks, 30 percent as all-time doves and 24 percent as swinging camps. The rest remained

\footnotetext{
${ }^{5}$ Due to the particularity of the exercise the process involved human reading rather than text mining/reading algorithms.
} 
unknown. When aggregated at the FOMC level, I find that the hawk and dove composition of the FOMC varied substantially during 1960-2015, featuring hawkish and dovish majorities. The variation in the hawk-dove measure is due to the annual rotation of the four Reserve Bank presidents, to members' turnover and in specific periods, to swingers, describing FOMC members whose preferences are perceived as switching over time. Large swings in preferences are observed in relation the state of the economy (i.e. the Great Inflation of the 1970s) but also in relation to intensified discussions on price stability and inflation targets in the early 1990s and following Greenspan's view on productivity and inflation in the late 1990s. ${ }^{6}$ Within the FOMC, the Reserve Bank Presidents are systematically perceived as hawkish while the Board of Governors is perceived to switch often between the dovish and hawkish majority. ${ }^{7}$

Hawk and Dove is a subjective measure as it describes perceived preferences and not necessarily the true preferences of FOMC members, which are not observable. However, a legitimate question is whether these perceptions capture "true" tendencies? To investigate this question I compare perceptions with actions (preferred rates, votes, forecasts) of each FOMC member over time, whenever available. Importantly, due to institutional constraints these actions have not been observed in real time. FOMC votes have been made public immediately after the meeting only since 2002; preferred rates can be inferred only from FOMC transcripts that are released to public since 1990s with a five-year lag; and individual FOMC members forecasts are released since 1992 with a ten-year lag policy. ${ }^{8}$ Overall I find a strong match of hawk and dove perceptions with member's actions: (i) majority of hawkish (dovish) preferred rates belong to perceived hawks (doves), (ii) dissents for tighter policy are predominantly cast from perceived hawks (about 86 percent of them) and dissents for ease are cast from perceived doves (79 percent), and (iii) perceived hawks tend to forecast on average a higher inflation than doves.

Moreover, the evolution of the Hawk-Dove measure at the FOMC level goes in line and provides support to important narratives on political dynamics and monetary policy since the 1960s. For instance, with regard to the start of the Great Inflation in the mid to late 1960s, Meltzer (2005) argues that despite his many

\footnotetext{
${ }^{6}$ See Bordo and Istrefi (2018) for a more detailed discussion on the making of hawks, doves and swingers in the FOMC.

${ }^{7}$ Real time perceptions based on news coverage go well in line with ex-post observations from voting records and internal records of FOMC deliberations, as in Belden (1989) and Chappell et al. (2005), among others. This research usually also finds Board Governors to prefer more expansionary policy than Reserve Bank presidents.

${ }^{8}$ Preferred interest rates for each member derive from FOMC transcripts as collected (measured) by Chappell et al. (2005), for the period 1970-1978 and 1987-1996. These transcripts have become available to public during the beginning of the 1990s and are issued with a five-year lag.
} 
warnings about inflation, Chairman Martin would wait months until a majority was formed, what contributed to delays in taking prompt anti-inflationary action. ${ }^{9}$ The Hawk-Dove measure shows that Martin faced a dovish majority in this period, explaining why it might have been hard for him (perceived to be in the hawkish minority) to reach a consensus and take prompt actions. By contrast, during the 1970s the FOMC is perceived to have had a hawkish majority (about 60 to 70 percent), somewhat surprising ex-post, given the outcome of the Great Inflation. This is not puzzling in light of the hypothesis that bad inflation outcomes of the 1970s reflect mistakes of well-meaning, optimally behaving central bankers, given what they knew about the economy in real time (see Orphanides (2000); DeLong (1997); Romer and Romer (2002); Primiceri (2006) among others). ${ }^{10}$ However, I also find that a part of these hawks of the 1970s are made up of swingers as some of the doves of the 1960s turned into hawks because inflation became a big problem.

Given their importance in understanding the making of monetary policy, a number of studies have been devoted to quantifying empirically the monetary authority's preference. The literature has mostly looked at policy preferences in aggregate, using reaction functions, but also for individual member preferences in cases where monetary policy is a committee decision. For instance, a large literature estimates monetary policy reaction functions of the form proposed by Taylor (1993) that relate a policy instrument (e.g., the Federal funds rate) to past or expected macroeconomic conditions (see Levin et al., 1999; Richard Clarida and Gertler, 2000; Owyang and Ramey, 2004; Levin et al., 2003). Often, parameters in front of the macro variables included in the rule (usually inflation and the output gap) are referred to as the policy preference of the monetary authority. However, Alt and Woolley (1982) have noted that reaction functions do not directly reveal the preferences of policymakers about alternative macroeconomic outcomes, as they depend not only on policymaker preferences, but also on their perceptions of structural macroeconomic relationships. While these studies target the true preference of the central banker, my contribution is to provide a novel measure of perceived preferences, to my knowledge not studied before in the literature.

To the extent that the perceived preferences of the FOMC can be used as a proxy for the true preference of individual members, this measure offers superior information to the common approach that relies on voting records and particularly on dissents to infer the policy preference of the FOMC members. ${ }^{11}$ The advantage of

\footnotetext{
${ }^{9}$ Meltzer (2005) highlights the role of leadership and beliefs of Federal Reserve policymakers as crucial elements to explain the origin of Great Inflation.

${ }^{10}$ The policymakers' misperceptions about the state of the economy (like potential output gap, natural rate of employment and the persistence of inflation) hypothesis of Great Inflation.

${ }^{11}$ Belden (1989) and Chappell et al. (2005) among many others, have looked at voting records
} 
the Hawk and Dove measure to existing proxies of policy preferences is that it can be measured in real time, being fed by information from personal background of these members, their expressed economic beliefs in speeches and votes or dissents when they become public. ${ }^{12}$ As such, it can be measured for most of FOMC members, even if they never dissent. Dissents are very rare and few FOMC members dissent enough and in one direction to be able to assign a stable preference. The HawkDove measure assigns a unique policy preference to 93 percent of FOMC members while only 37 percent of them have dissented at least twice (and fewer of them in the same direction). Furthermore, the Hawk and Dove measure allows studying the persistence of these preferences, identifying three types: the persistent hawk, the persistent dove and those that switched camps over time, i.e. the swingers.

Overall, this paper builds a hawk-dove measure for the FOMC and it shows that it is informative of individual FOMC member's actions and the dynamics of the FOMC. This measure can be used for several research purposes. Foremost, this measure can prove helpful to investigate questions that relate to market perceptions on who is in majority, the hawks, the doves or a balance, with market expectations on future path of monetary policy or inflation expectations. ${ }^{13}$ Perceptions on the balances within the FOMC might prove especially important in cases when the economic data do not suggest a clear direction. Furthermore, the hawk-dove measure of the FOMC could be used to learn about monetary policy shocks given exogenous changes in the composition of the preferences due to the rotation of voting rights of Reserve Bank presidents, among other interesting questions.

When used for these purposes, two important issues that have not been dealt with here should be considered. First, to deal with the concern that Hawk and Dove could be conditional on the state of the economy (as the result on swingers reveals), the Hawk-Dove balance should be corrected for the state of the economy as known in real time. For instance, it can be corrected with Greenbook forecasts for inflation and growth which are prepared by the Board's staff several days before the FOMC meeting. Another important issue is the weight of preferences of FOMC members. In this paper, the preference of each FOMC member receives the same weight when forming the composition of the FOMC in terms of hawks and doves. When studying

or textual records of committee deliberations as proxies of true policy preferences of the FOMC members.

${ }^{12}$ Prior to 1967 , the FOMC records of policy actions and votes were published only in the Board's Annual Report to Congress. Between mid-1967 to the beginning of 1975, the FOMC published the Record of Policy Actions with 90 days of delay. In 1975 it was shortened to 45 days.

${ }^{13}$ For instance, Riboni and Ruge-Murcia (2014); Ehrmann and Fratzscher (2013) have shown that dissenting views among monetary policy makers may affect the predictability of monetary policy decisions. 
the effect of this composition for (expected) outcomes, let say for the interest rates or inflation, it might be important to assign a higher weight to the preference of the Fed Chair. Therefore, different weighting strategies of these preferences could be considered.

Finally, given that Hawk and Dove is a perception on the policy preference, a direct mapping to policy preferences as discussed in theory is not straightforward. The public observes FOMC members leaning towards the dual mandate or the patience or impatience of members to change monetary policy to reach one or both legs of the dual mandate, and summarises this observation as hawkish or dovish. There could be different reasons why FOMC members have these leanings or impatience, be it different preference for the inflation target, a different reading of the data, a different model of the economy, and so on. These issues are abstracted from the discussion of perceptions of the policy preference, as what ultimately matters for financial markets' decisions is the perception and not the unobserved true preference of these members. A formal discussion of mapping of policy preferences as observed in practice with theoretical counterparts in a loss function or in a typical reaction function of the central bank is left for future research.

The structure of the paper is as follows. Section 2 presents the methodology to quantify perceived preferences and their evolution during the period 1960-2015. Section 3 provides a discussion whether the Hawk-Dove measure captures "true" tendencies of the FOMC. Section 4 concludes.

\section{Perceived policy preferences of the FOMC}

This section starts with a detailed exposition of the steps followed to derive the measure of perceived policy preferences. Following the methodology, the evolution of perceived preferences throughout 1960-2015 is discussed.

\subsection{Methodology}

The hawk-dove measure of the FOMC is based on narrative records in the media. Qualitative information on preferences is extracted from newspaper articles, financial media outlets and business reports of Fed watchers in the US. The narrative record in the media is used as a public source and a filter of all relevant information to guess the central banker's type. This includes information with regard to members personal background, political interests, political supporters, expressed economic beliefs before joining and during their time at the Federal Reserve and policy actions (votes and dissents). This information is used to feed the perceptions of market 
participants on the policy leanings of each FOMC member. To capture perceptions there have been consulted about 20,000 articles or reports with reference to FOMC members. ${ }^{14}$ Articles are read from more than 30 newspapers, including among others, the Chicago Tribune, The New York Times (NYT), The Wall Street Journal (WSJ) or Financial Times. The sources for the newspapers used are: Proquest, Newspaper Archiver, Factiva. Financial reports from different market strategy firms are mostly available online in recent years. ${ }^{15}$

A reading of narrative records since the early 1960 shows that beliefs on the policy preferences of individual FOMC members have been expressed in different terms and those terms have evolved through time. For instance, in the beginning of the 1960s the most used terms to summarize the policy leanings of individual members were: conservative, liberal, monetarist, tight or easy money guy. The terms hawk and dove for central bankers gained popularity after the Vietnam War. ${ }^{16}$ A reference from Dow Jones Capital Markets Report in 2005 explains the hawk-dove categorization as follows: "Market participants tag central bankers in avian terms, seeking to describe officials' inflation fighting appetites. Hawks are central bankers who put the inflation fight high above other goals. Dovish Fed members, meanwhile, have historically been inclined to tolerate a bit more price pressures, or at least the threat of them, if it allowed higher growth and better job gains." For members whose preferences are believed not to strongly belong in one of the camps, terms like middle of the road-er, swinger, pragmatic, eclectic or centrists are used.

Perceptions on policy preferences are not always summarized in a word, like the ones above. Often, perceptions on policy preference can be inferred whenever an FOMC member is cited about his or her positions with respect to (the actual or future) inflation and economic growth (unemployment, recession risks) or the preferred direction of policy (either money supply or interest rates) as a function of the most pressing economic problem to them, inflation or output. In most cases, the FOMC members are compared to each other, therefore the perceived policy preference for one member is relative to the other members in the same FOMC.

Some examples of quotes from press articles that can inform on perceptions of

\footnotetext{
${ }^{14}$ Due to the specificity of the exercise, all articles have been screened and read by the author of the paper and one research assistant and not by text searching algorithms.

${ }^{15}$ Some additional outlets are Reuters, Dow Jones Newswire, Los Angeles Times, Baltimore Sun, The Washington Post, American Banker, The Associated Press, Market News International, International Business Times, Investors Business Daily, Market Insight. The sources for the newspapers used are: Proquest Historical Newspapers with Los Angeles Times, Chicago Tribune, NYT, 1960-1999; Proquest with WSJ, Baltimore Sun, Washington Post, Chicago Defender, 1960-1999; Newspaper Archiver for regional newspapers, 1958-1990 and Factiva for 1985-2015.

${ }^{16}$ These terms were initially used in relation to politicians' budget attitudes toward the Vietnam war budget.
} 
the policy preference of the FOMC member are the following: "inflation hawk", "inflation dove", "an avowed inflation-fighter", "will follow a moderately restrictive monetary policy until the present inflation - which he still considers the No 1 economic problem - has been eliminated", "he leans toward tight-money policies and high interest rates to retard inflation", "believed that further tightening might be necessary, but they were concerned about what they perceived as growing signs that the recession was in full cry", "likely to vote against a discount-rate increase out of their concern regarding economic performance", "When President Reagan appointed to the board three members described as supply-siders [...] monetary policy analysts and the press predicted a more expansionary and inflationary Fed policy would result", "inflation-obsessed 'hawks'", "where they stand on a spectrum from hawk - those more concerned about inflation - and dove - members more concerned about growth.", "one of the most outspoken among the minority of so-called hawks at the Fed, has called for acting before the year is out, citing improvement in the housing market, which the stimulus was partly designed to support by lowering long-term interest rates", "her reputation as a dove has many investors thinking she'll argue for a prolonged low-rate policy at tomorrow's testimony, a stance aimed at helping job growth even if it means somewhat overshooting the Fed's long-run inflation target".

Following the financial markets' language, I summarize the information from narrative records on the preferences of FOMC members with two main qualitative terms - Hawk and Dove. Steps for arriving at these two categories are as follows:

1. For each FOMC member, search for articles that contain this name (articles before and during the time in office).

2. Read and identify parts in the article with reference to the policy preference of the FOMC member. Save this information.

3. Evaluate the saved information and assign a policy preference to it, in one of the following categories: Expected Hawk, Expected Dove, Hawk, Dove, Unknown.

4. Assign the perceived policy preference accordingly in years it is observed.

Below I discuss in more detail and give examples for the five categories of perceived policy preferences: Expected Hawk, Expected Dove, Hawk, Dove, Unknown. Examples will be given for the seven Fed Chair persons since 1960 to 2017, William McChesney Martin, Arthur Burns, G. William Miller, Paul Volcker, Alan Greenspan, Ben Bernanke and Janet Yellen. 
Expected hawk, Expected dove. This policy preference is assigned to FOMC members that vote for the first time in the FOMC and some public debate on their policy leanings already exists. For members of the Board, expected policy leanings are usually discussed during periods when the future member is either a candidate for the Board nominated by the President and waiting for Senate confirmation, or it is a confirmed member that is expected to sit on the FOMC at a later date. For Federal Reserve Bank presidents, these expectations are usually discussed when they are newly appointed but have not yet voted in the FOMC due to their rotation scheme in the FOMC. Clues to the policy leanings of these members are often taken from their personal backgrounds (the origin, education, profession), their earlier writings or positions with respect to economic debates, the ideology of the appointee (a Democrat or a Republican US president or a Federal Reserve Bank with established institutional memory) or who is supporting the candidate (i.e. the liberals or the conservatives in the Senate).

Table 1 shows selected examples of expected policy preferences for Arthur Burns, G. William Miller and Alan Greenspan when they were nominated as the Federal Reserve chair. ${ }^{17}$ For Paul Volcker, Ben Bernanke and Janet Yellen these expectations correspond to their first stints in the FOMC that did not correspond with the position of the Federal Reserve chair. Initially, Paul Volcker was the president of the Federal Reserve of New York (1995-1979) and Janet Yellen and Ben Bernanke were Board members, in 1994-1997 and 2002-2005, respectively. The identification of preferences for the rest of the FOMC members follows the same logic. As quotes in Table 1 and many others collected for them before they entered in the FOMC show, Burns, Volcker, Greenspan and Bernanke were expected to be hawks and Miller and Yellen, doves. ${ }^{18}$

Hawk, Dove. These perceptions are assigned to members for which clues on policy preferences can be inferred, in addition, from positions that these members take while in the FOMC, i.e. either through votes, speeches or testimonies. These positions can either reinforce or reverse the expected hawk/expected dove perceptions. Once at the FOMC, hawk and dove perceptions of each member are followed over their entire FOMC stint. This allows to build a history of how preferences have been perceived over time, either as persistent or not (i.e. swinging from a hawk to a dove or vice versa). Table 2 illustrates these cases for the seven Federal Reserve chairpersons in the sample. William McChesney Martin is the longest-serving chairman of the Federal Reserve, serving from 1951 to 1970. My sample covers his last ten years

\footnotetext{
${ }^{17}$ William McChesney Martin became the chairman of the Federal Reserve in 1951, a period not covered in my sample.

${ }^{18}$ Appendix A gives a more detailed discussion on perceptions about these Fed Chairpersons.
} 
Table 1: Assigning perceived policy preferences: Expected Hawk/Expected Dove

\begin{tabular}{|c|c|c|c|}
\hline Name & Policy preference & Newspaper quote & Source \\
\hline Arthur Burns & $\begin{array}{l}\text { Expected } \\
\text { Hawk }\end{array}$ & $\begin{array}{l}\text { "Dr. Burns writing and his record in Gov- } \\
\text { ernment "point to a determined and effective } \\
\text { policy of ending our inflationary spiral"' Dr. } \\
\text { Kaufman also said. The selection was viewed } \\
\text { as convincing proof that the federal govern- } \\
\text { ment's anti-inflation program will be contin- } \\
\text { ued until it succeeds in making prices rise less } \\
\text { rapidly." }\end{array}$ & $\begin{array}{l}\text { Nomination of Burns Viewed } \\
\text { As Reassurance in Price Fight: } \\
\text { Economist and Businessmen } \\
\text { Convinced the Move Means } \\
\text { Government Will Continue } \\
\text { Anti-Inflation Program. New } \\
\text { York Times, } 18 \text { October } 1969 .\end{array}$ \\
\hline G. William Miller & $\begin{array}{l}\text { Expected } \\
\text { Dove }\end{array}$ & $\begin{array}{l}\text { "More crucial to the outlook is the confirma- } \\
\text { tion of Miller and the direction of his leader- } \\
\text { ship if he becomes chairman. "My guess is that } \\
\text { he is going to be fairly liberal with monetary } \\
\text { growth," Mr Sprinkel said."** }\end{array}$ & $\begin{array}{l}\text { New Faces on Fed Commit- } \\
\text { tee Confuse Credit Markets: } \\
\text { Faster Money. New York } \\
\text { Times, } 27 \text { February } 1978 .\end{array}$ \\
\hline Paul Volcker & $\begin{array}{l}\text { Expected } \\
\text { Hawk }\end{array}$ & $\begin{array}{l}\text { "Mr. Volcker, who will take over his new } \\
\text { post Aug.1, will hold what is widely considered } \\
\text { the nation's second most important monetary } \\
\text { policy-making position - after the Federal Re- } \\
\text { serve chairmanship, held by Dr. Arthur Burns. } \\
\text { He is considered philosophically sympathetic } \\
\text { with Dr. Burns, which means, for example, } \\
\text { that he leans toward tight-money policies and } \\
\text { high interest rates to retard inflation. But he } \\
\text { is also thought to be less ideological than the } \\
\text { Fed chairman." }\end{array}$ & $\begin{array}{l}\text { A Monetary Pragmatist: Paul } \\
\text { Adolph Volcker. New York } \\
\text { Times, } 2 \text { May } 1975 .\end{array}$ \\
\hline Alan Greenspan & $\begin{array}{l}\text { Expected } \\
\text { Hawk }\end{array}$ & $\begin{array}{l}\text { "Like Mr. Volcker, Mr. Greenspan is an } \\
\text { avowed inflation-fighter who believes that ex- } \\
\text { cessive growth of the nation's money supply is } \\
\text { the primary cause of inflation." }\end{array}$ & $\begin{array}{l}\text { Man in the news; A Laissez- } \\
\text { Faire Pragmatist: Alan } \\
\text { Greenspan, New York Times, } \\
\text { June 3, 1987. }\end{array}$ \\
\hline Ben Bernanke & $\begin{array}{l}\text { Expected } \\
\text { Hawk }\end{array}$ & $\begin{array}{l}\text { "On monetary policy, Mr. Bernanke, who ad- } \\
\text { vocates the Fed set inflation targets to main- } \\
\text { tain price stability, is "closer to hawkish but } \\
\text { he's very mainstream," said New York Uni- } \\
\text { versity economist Mark Gertler, who has co- } \\
\text { written papers with him." }\end{array}$ & $\begin{array}{l}\text { Bush Chooses Two To Fill Fed } \\
\text { Vacancies. Wall Street Jour- } \\
\text { nal, } 9 \text { May } 2002 \text {. }\end{array}$ \\
\hline Janet Yellen & $\begin{array}{l}\text { Expected } \\
\text { Dove }\end{array}$ & $\begin{array}{l}\text { "And the balance of power within the Fed is al- } \\
\text { ready shifting toward the 'inflation doves'. Mr } \\
\text { Blinder and Ms Yellen are competent macro- } \\
\text { economists. But as self-proclaimed 'pragma- } \\
\text { tists' in the Keynesian tradition, they are cer- } \\
\text { tain to be less hawkish than the Republican } \\
\text { appointees they replace. And as future Fed va- } \\
\text { cancies arise, the tilt towards 'growth-oriented' } \\
\text { policies will become more pronounced." }\end{array}$ & $\begin{array}{l}\text { Monetary credentials still in } \\
\text { doubt. Financial Times, } 25 \\
\text { April } 1994 .\end{array}$ \\
\hline
\end{tabular}

Note: ${ }^{* *}$ Confirmation of Miller was done in March 1978. New York Times refers to Beryl W. Sprinkel which at the time was the chief economist at Harris Bank and later the chairman of the Council of Economic Advisors during 1985 - 1989. 
(1960-1970), e period through which he is always perceived as a hawk. Overall, the policy positions taken during the FOMC term (either as Federal Reserve chair or not), reinforced the expected preferences as discussed previously for Burns (hawk), Miller (dove), Volcker (hawk) and Yellen (dove). The expected hawk perception for Greenspan was also confirmed for most of his term while for Bernanke it was reversed from the start.

Out of the seven cases, probably the perception of Burns as a hawk might come as a surprise for some readers that have in mind the high rates of inflation during the 1970s and stories told about Burns being politically pressured to pursue an expansionary policy (see Abrams (2006)). However, narratives in press during these years suggests that Burns and his FOMC are regarded as 'overly concerned with inflation rather than fighting the recession' or Burns is cited arguing that 'the nation should strive for a "zero" inflation rate'. ${ }^{1920}$ Along these lines, Hetzel (1998) argues that, in those years, 'for the public, and especially for the business community, Burns embodied opposition to inflation.' Furthermore, Romer and Romer (2004) also argue that 'one constant in Burns's beliefs was a conviction that inflation was very costly. [...] While Burns's concern for inflation never varied, what did change over his career were his beliefs about the policies necessary to control it'.

Unknown. For many FOMC members, the existing information (as discussed in the media) at the time they are related with the FOMC does not help in building an expectation on hawkish or dovish leanings. These members enter the FOMC with "unknown" preferences. Whether they assign a higher priority to output or inflation becomes known as they vote for policy and have public speeches. For instance, the quotes from NYT with respect to Robert T. Parry (Federal Reserve Bank of San Francisco, 1986-2004) suggests that policy leanings of Mr. Parry are yet unknown in late 1985: "Mr. Parry seemed reluctant to classify himself as a member of any particular monetary philosophy. "My background is in the classical school of economics," he said. "I suppose that's because I went to school in the 60's and not more recently. I can't put myself in the school of monetarists or supply-siders. I'm willing to look at a problem from a lot of different views. It's just hard for me to identify the religion." 21 Later, his speeches and votes suggested a hawkish policy

19 "Mr. Burns and his colleagues, maintain the critics, first helped bring on the recession by tightening up on the money supply and forcing interest rates too high, and now are prolonging the economic downturn by being overly concerned with inflation rather than fighting recession." ROUNDUP: America's Money Managers, New York Times, 6 April 1975.

20 "Chairman Arthur F. Burns of the Federal Reserve Board warned Congress Wednesday of "very troublesome signs" of a new outburst of inflation that could slow the nation's recovery from recession. He also said the nation should strive for a "zero" inflation rate." Inflation could slow recovery, Fed chief says, Chicago Tribune, 29 January 1976.

${ }^{21}$ Fed Bank on Coast Names President, New York Times, 24 December 1985. 
Table 2: Assigning perceived policy preferences: Hawk/Dove

\begin{tabular}{|c|c|c|c|}
\hline Name & Policy preference & Newspaper quote & Source \\
\hline Martin & Hawk & $\begin{array}{l}\text { "But Mr. Martin has become a sort of sym- } \\
\text { bol, at home and abroad, of a noninflation- } \\
\text { ary monetary policy that would permit inter- } \\
\text { est rates to rise and would curb monetary ex- } \\
\text { pansion, at times when the economy is threat- } \\
\text { ened by excessive borrowing and spending and } \\
\text { rising prices. Last year was a perfect example. } \\
\text { Money was made extremely tight. And after } \\
\text { an initial split, Mr Martin had his whole board } \\
\text { with him." }\end{array}$ & $\begin{array}{l}\text { Martin's Future Is Johnson's } \\
\text { Problem, New York Times, } 26 \\
\text { March 1967. }\end{array}$ \\
\hline Arthur Burns & Hawk & $\begin{array}{l}\text { "If Arthur Burns has his way, the Federal Re- } \\
\text { serve Board will continue to follow a mod- } \\
\text { erately restrictive monetary policy until the } \\
\text { present inflation - which he still considers the } \\
\text { No } 1 \text { economic problem - has been eliminated. } \\
\text { " }\end{array}$ & $\begin{array}{l}\text { Until inflation disappears: Fed } \\
\text { Chief Seeks Continued Tight } \\
\text { Money FED POLICY, Los An- } \\
\text { geles Times, } 23 \text { October } 1973 .\end{array}$ \\
\hline G. William Miller & Dove & $\begin{array}{l}\text { "Coldwell, Wallich, Kimbrel joined Volcker in } \\
\text { voting for "some additional firming in money- } \\
\text { market conditions" to try to check inflation. } \\
\text { [... The Volcker minority took the view that } \\
\text { "inflation represented the greatest risk to eco- } \\
\text { nomic stability" the summary said, while the } \\
\text { Miller majority, "believed that the chances of a } \\
\text { recession beginning before the end of the year } \\
\text { or early } 1980 \text { were fairly high." }\end{array}$ & $\begin{array}{l}\text { Fed Policy Unit Rejected } \\
\text { Tighter Credit in March: Fed } \\
\text { Vote On Credit, New York } \\
\text { Times, } 21 \text { April 1979. }\end{array}$ \\
\hline Paul Volcker & Hawk & $\begin{array}{l}\text { "In the first two months of his term, Paul Vol- } \\
\text { cker engineered the fastest increase in short- } \\
\text { term interest rates since the Federal Reserve } \\
\text { was created early in the century. Then, on Oct. } \\
6 \text {, he won approval to make radical, inflation- } \\
\text { fighting revisions in the way that the Federal } \\
\text { Reserve controls the money supply in order to } \\
\text { stem its growth." }\end{array}$ & $\begin{array}{l}\text { Some Who Captured Head- } \\
\text { lines: The Interest Focuses On } \\
\text { Volcker, New York Times, } 2 \\
\text { January } 1980 .\end{array}$ \\
\hline \multirow[t]{2}{*}{ Alan Greenspan } & Hawk & $\begin{array}{l}\text { "Of the seven Federal Reserve Board members, } \\
\text { some are less tolerant of inflation than others, } \\
\text { notably Wayne Angell and possibly Chairman } \\
\text { Greenspan and the newest member, John P. La } \\
\text { Ware, the only Democrat. Martha R. Seger, } \\
\text { Manuel Johnson, H. Robert Heller and Edward } \\
\text { W. Kelley Jr. have shown little or no commit- } \\
\text { ment to reducing inflation to a negligible rate." }\end{array}$ & $\begin{array}{l}\text { Ridding America of Chronic } \\
\text { Inflation, The Washington } \\
\text { Post, } 10 \text { February } 1989 .\end{array}$ \\
\hline & Dove & $\begin{array}{l}\text { "Contrary to his reputation as a hard-nosed } \\
\text { inflation fighter, Greenspan has, in the words } \\
\text { of one Fed watcher, proven to be a "dove in } \\
\text { hawk's clothing." He successfully fought off } \\
\text { pressure within the Fed for an interest rate in- } \\
\text { crease last year ahead of the November presi- } \\
\text { dential election." }\end{array}$ & $\begin{array}{l}\text { Clinton given chance to stack } \\
\text { Fed with Democrats, Reuters } \\
\text { News, } 11 \text { January } 1997 \text {. }\end{array}$ \\
\hline \multirow[t]{2}{*}{ Ben Bernanke } & Dove & $\begin{array}{l}\text { "Bernanke is widely seen as a deflation fighter } \\
\text { and not an inflation warrior. So for better } \\
\text { or worse he is perceived as more dovish than } \\
\text { Greenspan (who was perceived as more dovish } \\
\text { than Paul Volcker)." }\end{array}$ & $\begin{array}{l}\text { FX Analytics Focus: Drum } \\
\text { Roll...The Next Fed Chairman, } \\
\text { Dow Jones Capital Markets } \\
\text { Report, } 19 \text { October } 2005 .\end{array}$ \\
\hline & Dove & $\begin{array}{l}\text { "The weakness of Treasury prices and higher } \\
\text { yields was seen reflecting the view that } \\
\text { Bernanke will be "pro-growth" and perhaps } \\
\text { less hawkish on inflation, said John Roberts, } \\
\text { managing director at Barclays Capital in New } \\
\text { York" }\end{array}$ & $\begin{array}{l}\text { Treasury's Stabilize After } \\
\text { Bernanke Tapped As New Fed } \\
\text { Chmn, Dow Jones Capital } \\
\text { Markets Report, } 24 \text { October } \\
2005 .\end{array}$ \\
\hline Janet Yellen & Dove & $\begin{array}{l}\text { "Doves are in the ascendance, however. Their } \\
\text { camp counts Chairman Ben Bernanke, his sec- } \\
\text { ond in command, Janet Yellen, and New York } \\
\text { Fed President William Dudley. [...] It was the } \\
\text { doves who authored the new stimulus effort the } \\
\text { Fed put in place a week ago." }\end{array}$ & $\begin{array}{l}\text { FED WATCH; Kocherlakota } \\
\text { Completes Extreme Swing } \\
\text { from Hawk to Dove, The Wall } \\
\text { Street Journal, } 20 \text { September } \\
2012 \text {. }\end{array}$ \\
\hline
\end{tabular}


preference. For instance, WSJ in 1988 writes: "And in a speech in Hong Kong Monday, San Francisco Fed President Robert Parry, a member of the Fed's policy committee, said he is "less concerned with a potential slowdown in U.S. business activity than I am with the possibility of overheating activity and the threat of rising inflationary pressures." 22 Preferences can also remain unknown forever, which is the case for members that stayed for a short time in the FOMC and/or where not vocal. ${ }^{23}$

To summarize, I code four categories: Expected Hawk, Hawk, Expected Dove and Dove. Information on policy preferences is collected for each FOMC member that served between the period 1960 until 2015. This period comprises 130 members. In the beginning of the sample this type of information is scarce for members that are not very vocal or are new in the FOMC to know something about them. For these years all available articles with reference to the FOMC member is read and used for the coding. After the 1990s there are abundant articles with reference to most of the FOMC members. On the coding process, there are some decisions to be taken. For instance, if there is no new information that contradicts the previous perception on a particular member, the preference is kept unchanged. Next, if for a particular member different sources seem to suggest a different policy preference, I take the majority view. Finally, if for a particular member newspapers reports actions that do not match their 'words', I assign more weight to the action. This means, if at the same time, newspapers quote the speech of a member and the vote, and the two do not match, I give priority to the signal from the vote.

\subsection{Perceived Hawks and Doves in the FOMC}

Below I show the results from the quantification of perceptions as Hawk or Dove at the individual and at the FOMC level.

\subsubsection{Hawks, Doves and Swingers: Individual level}

Following the methodology as described above, a Hawk or Dove categorisation is given to 93 percent of the 130 members that served during the period 1960-2015. ${ }^{24}$ The rest remained unknown. Looking at the evolution of individual member's policy preferences over the time spent at the FOMC I observe that they are not necessarily static. For some periods a member is perceived as a hawk and for some others a

\footnotetext{
${ }^{22}$ Fed Hopes to Avoid Discount-Rate Rise As It Seeks to Head Off Inflation Threat, The Wall Street Journal, 1 June 1988.

${ }^{23}$ In these cases there are very few to none press articles mentioning the member and those references do not relate to policy preferences.

${ }^{24}$ Expected Hawk and Expected Dove are part of the Hawk and Dove count, respectively.
} 
dove, or vice versa. Market participants seem careful to observe that some FOMC members are having a different leaning from what was perceived before, either by observing the votes or new positions taken in speeches, and update accordingly.

Investigating each FOMC member for the time serving at the FOMC, I observe there are members that have been always perceived as one type (a hawk or a dove) and members for which the perception on the type has varied through time. I summarize this information in three categories: persistent hawks, persistent doves and swingers. Persistent hawks (doves) are those FOMC members for whom perceptions on preferences have been of one type only. Swingers are FOMC members for whom perceptions on preferences have varied over time. I find that 69 percent of all FOMC members are perceived to have had persistent preferences. Within this group, 39 percent are persistent hawks and 30 percent are persistent doves (see Table 3). From the remaining, about 24 percent of the FOMC members constitute the swingers. ${ }^{25}$

Generally, market participants seem able to make the distinction if a particular leaning of an FOMC member in a given time constitutes a shift in preferences or just a temporary position due to circumstances. As an example, I highlight a quote from WSJ in 2002, referring to Alfred Broaddus Jr., President of the Federal Reserve Bank of Richmond in the period 1993-2004. In this discussion, Broaddus is referred to as a long time hawk and market specialists discuss if his worries about deflation in 2002 mean that he had a change of heart or they reflect a change of circumstances. "That a die-hard inflation hawk such as Mr. Broaddus now talks of the dangers of inflation going too low has raised eyebrows both inside and outside the Fed. One fellow policy maker has started referring to him as the "leading dove" Mr. Broaddus says. Yet people who have watched Mr. Broaddus consider the apparent change consistent with his commitment to price stability, which means battling both inflation and deflation... "It's not a change of heart" says Mr. Meltzer, the Carnegie Mellon economist. "It's a change of circumstance." 26

Admittedly, there have been cases in the history of the FOMC where its members are perceived to have had a "change of heart". The most recent example is that of Narayana Kocherlakota, President of the Federal Reserve Bank of Minneapolis during 2009-2015. When he was assigned to the position of the Federal Reserve Bank president, markets perceived him to be a hawk (preference coded as Expected hawk). By 2011, he was a noted hawk, arguing against further monetary easing and suggesting that the Fed has become tolerant to inflation. However, by 2012,

\footnotetext{
${ }^{25}$ For some FOMC members, the perception is that they switch more than once.

${ }^{26}$ The Flip Side: Inflation Subdued, Top Hawk At Fed Frets Over the Opposite - Mr. Broaddus Helped Reach Goal of "Price Stability" But Is Deflation a Danger? May 2002, The Wall Street Journal.
} 
Kocherlakota made a complete shift from hawk to dove and market participants updated their perceptions on him accordingly. WSJ (2012) refers to this case as follows: "In the nearly three years Narayana Kocherlakota has held the keys to the Minneapolis Fed, the central banker has undergone a pronounced evolution from hawk to dove, in a shift made complete Thursday. In a speech Thursday in Michigan, Mr. Kocherlakota completed his shift. He noted he "liked" Mr. Evans's ideas...Mr. Kocherlakota's Thursday speech caught some Wall Street observers totally off guard. Calling the official a "noted hawk," Eric Green, economist at TD Securities said the policy maker's path to his current view is "tortured". "In a matter of months a hawk moves from a premature exit strategy to raising the inflation target and then suggests keeping real fed funds at 50-year lows" even if that breaches what many consider to be inflation generating full-employment levels, Mr. Green said." ${ }^{27}$ The case of Kocherlakota is just one of several other swingers in the FOMC.

Table 3: Summary statistics: Persistent hawks (doves) and swingers

\begin{tabular}{lccccc}
\hline & Hawk & Dove & Swinger & Unknown & Total(\%) \\
\hline \hline FOMC(\%) & 39.2 & 30.0 & 23.8 & 6.9 & 100 \\
Position in FOMC & & & & & \\
Board of Governors & 14 & 31 & 12 & 0 & 43.8 \\
$\begin{array}{l}\text { Reserve Bank President } \\
\text { Gender }\end{array}$ & 37 & 8 & 19 & 9 & 56.2 \\
Male & 48 & 31 & 28 & 9 & 89.2 \\
Female & 3 & 8 & 3 & 0 & 10.8 \\
\hline \hline
\end{tabular}

Notes: Summary statistics for a total of 130 members serving in the FOMC during the period of 1960 to 2015.

Furthermore, Table 3 shows that when dividing Board of Governors versus Reserve Bank presidents, the former are perceived more in the dovish side and the latter in the hawkish side. The second most recurring type among Reserve Bank presidents is a swinger, while for the Board, the hawk and swinger types are balanced. In terms of gender, men in the FOMC are perceived slightly more on the hawkish side. Female FOMC members have been perceived mostly on the dovish side. However the sample (14 out of 130 members) is too small to assign significance to these numbers.

\footnotetext{
${ }^{27}$ FED WATCH; Kocherlakota Completes Extreme Swing from Hawk to Dove, 20 September 2012, The Wall Street Journal.
} 


\subsubsection{Hawks and Doves: FOMC level}

In the following, I discuss the evolution of hawks and doves at the FOMC level, over time. To understand the composition from individual data to the FOMC level, some basic information on the structure of the FOMC is necessary. The FOMC is made up of 12 members - seven members of the Board of Governors, the president of the Federal Reserve Bank of New York, and presidents of four other Federal Reserve Banks, who serve on a (pre-specified) annual rotating basis. The rotation scheme is such that nine Reserve Bank presidents vote one out of every three years. Presidents of the Federal Reserve Banks of Chicago and Cleveland vote in alternate years. ${ }^{28}$ This makeup of the FOMC suggests that its composition of personalities voting on monetary policy is in a continuous flux. The total of the FOMC members is not always 12, as often there are vacancies in the Board of Governors.

Knowing who sits in the FOMC in a particular meeting $m$, year $t$, I count how many of them are perceived as hawks, how many as doves and how many are unknown. ${ }^{29}$ In real time, there are only these three types: hawk, dove or unknown. In this count, I give to the preference of each voting member the same weight (one member, one vote, one preference). The perceived preference of each FOMC member participating in meeting $m$, year $t$ is based on information known before this meeting. This preference will be updated meeting by meeting if there is new information revealed before the meeting.

Figure 1 shows the share of hawks (including the expected hawks) and doves (including the expected doves) for the FOMC during the period 1960-2015. For each year, the Hawk and Dove composition corresponds to the new FOMC, i.e. the first meeting with the new rotation of the Federal Reserve Bank presidents. ${ }^{30}$ The dashed line displays the share of doves and the solid line the share of hawks. In this figure, at each meeting, I abstract from members the preferences of which are not known yet. As such, the share of hawks and doves does not add to 100 percent, at all times. The first panel corresponds to the total FOMC and the two other panels to the composition of preferences of the Board and of the Reserve Bank presidents, respectively.

There is substantial variation in the perceived Hawk/Dove scale of the FOMC throughout the entire period under consideration. Overall, it seems that markets

\footnotetext{
${ }^{28}$ Board Governors are appointed by the US president, with the approval of the US Senate for a 14-year term. Reserve Bank presidents are appointed for a 5-year term by his/her Bank's board of directors, with the approval of the Board of Governors.

${ }^{29}$ Expected Hawk and Expected Dove are part of the Hawk and Dove count, respectively.

${ }^{30}$ The first meeting of the new FOMC did not correspond with the first meeting of the year until 1979. The new FOMC would have the first meeting around March. Starting from 1979, the new FOMC meets on the first meeting of the year (either January or February).
} 
Figure 1: Perceived composition of FOMC preferences (1st meeting of new FOMC)

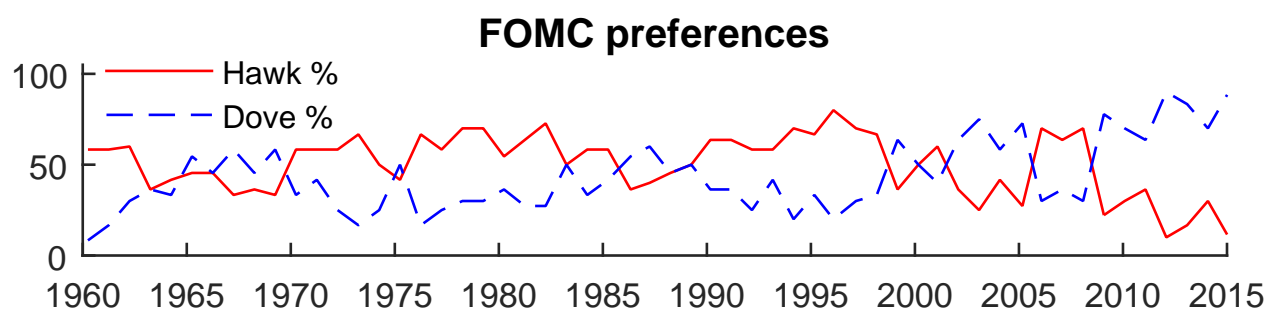

Board of Governors preferences

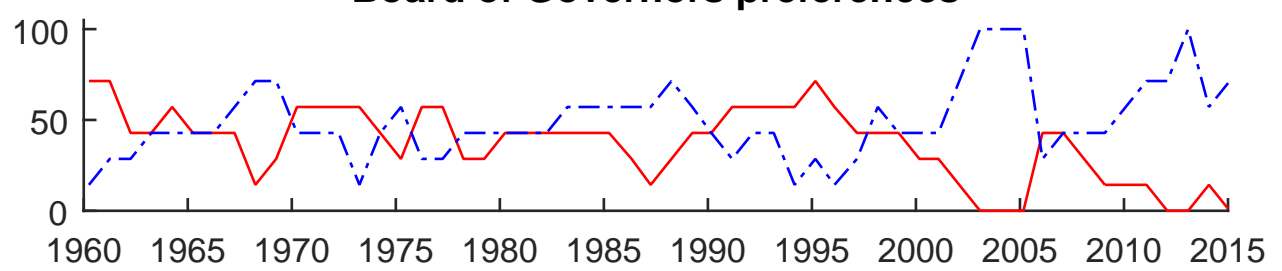

Regional Fed Presidents preferences

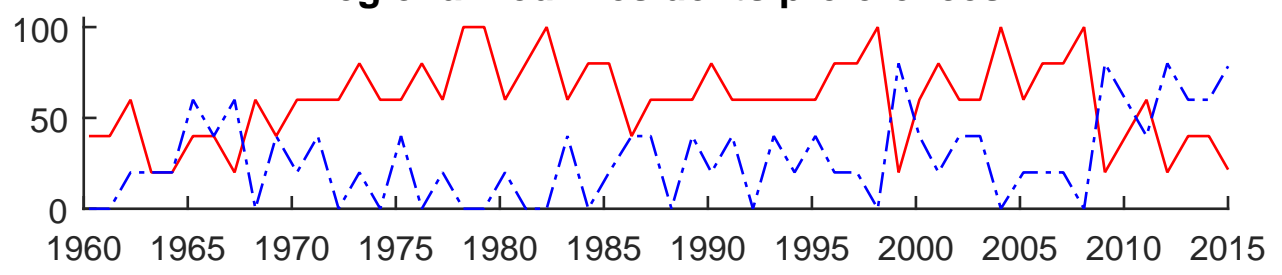

Notes: The share of doves and hawks over the total of FOMC members in a meeting. The shares do not add up to 100 when there are FOMC members with "unknown" preferences.

have perceived a hawkish FOMC, especially for the most part of Arthur Burns', G. William Miller's, Paul Volcker's and Alan Greenspan's years as Federal Reserve chairpersons. A dovish bias of the FOMC is perceived during the last years of almost all chairmen (Martin, Volcker, Greenspan and Bernanke). Janet Yellen joined an already dovish FOMC.

In more detail, the second panel shows that the Board of Governor's composition is perceived to switch often between the dovish and hawkish bias. On certain periods the Hawk/Dove score is relatively tight but there are periods were differences are considerable and persistent. The end of the 1960s, the most of the 1980s and since 2000 a strong dovish bias was perceived for the Board. Especially during 2002-2005 none of the Board Governors is perceived to have a hawkish preference (the chairman included).

The individual FOMC member preferences in Table 3 already showed that there is a difference between the Board and the Federal Reserve Bank presidents. Panel 2 and 3 of Figure 1 show that this difference has been systematic. Throughout the 
sample, the composition of rotating presidents is generally perceived as hawkish. This result matches fairly well those discussed in the FOMC literature, which usually finds that Board members appear to prefer more expansionary policies than the Reserve Bank presidents (see Belden (1989), Havrilesky and Gildea (1989) and Chappell et al. (2005)). However, during recent years, the perceived Hawk/Dove balance of (rotating) Federal Reserve Bank presidents seems to have reversed to the dovish side as well. Compared to the Board Governors, there is also more variation from year to year, mostly due to the voting rotation scheme.

Figure 2 shows the evolution of the Hawk/Dove composition of the FOMC, at meeting frequency since 1960. This figure depicts the shares of hawks and doves as perceived in real time (lighter red/blue areas) and the shares of persistent hawk$\mathrm{s} /$ persistent doves (the dark red/blue areas). The difference between the light and dark shades of each color represents the distribution of swingers over time. For example, the FOMC in 1995 was perceived to have a high share of hawks (60 percent). Nonetheless, none of these hawks were persistent or all-time hawks. The big swing waves are observed during the 1970s (the Great Inflation), during the 1990s (discussions on price stability and inflation targets) and early 2000s (following Greenspan's revelation on productivity and inflation in the late 1990s).

Figure 2: Perceived composition of FOMC preferences

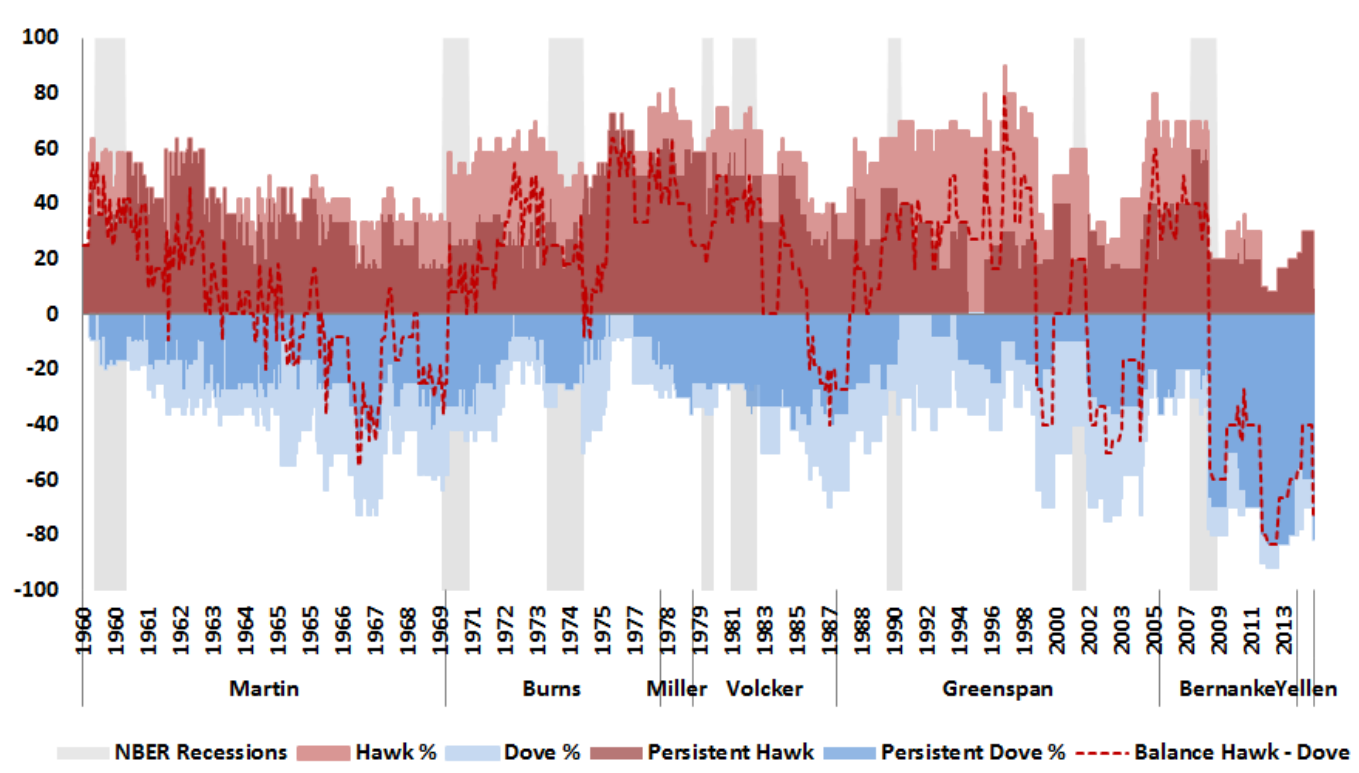

Notes: The share of doves (persistent doves) and hawks (persistent hawks) over the total of FOMC members, at meeting frequency. In real time, the shares of real time hawks and doves do not add up to 100 when there are FOMC members with "unknown" preferences. 


\section{Do perceptions capture "true" tendencies?}

Hawk and Dove is a subjective measure as it describes perceived preferences and not necessarily the true preferences of FOMC members, which are not observable. However, a legitimate question is whether these perceptions capture "true" tendencies? To investigate this question I first discuss how the hawkish and dovish dynamics in the FOMC match with what we know about the evolution of monetary policy in the US during this period from academic works that are based on FOMC transcripts or other methodologies. Next, I compare perceptions with actions (preferred rates, votes, forecasts) of each FOMC member over time, whenever available.

\subsection{Narratives from FOMC transcripts or research}

The dashed line in Figure 2 shows the Hawk-Dove balance (the share of hawks minus the share of doves), as perceived in real time. The evolution of the perceived Hawk-Dove balance for the FOMC goes in line and provides support to important narratives on political dynamics and monetary policy since the 1960s. For instance, Meltzer (2005) relates the origins of the Great Inflation mostly to the personality of the Fed chair and the economic beliefs at the time of the FOMC. Chairman Martin seems the most unlikely person to preside over monetary policy that eventually led to the Great Inflation. Martin was the longest serving Fed chair (1951-1970). He was considered an inflation hawk and the Fed under him had a very good track of low and stable inflation. But Martin believed that policy should be made by consensus. ${ }^{31}$ Dissents on policy in this period were high, up to 5 in one meeting, for both tighter and easier policies. With inflation picking up and a divided FOMC, Meltzer (2005) argues that Martin often waited, thinking that discussion, events, and perhaps collegiality would help form the consensus. To Melzer, this situation contributed to delays in taking prompt anti-inflationary action.

The Hawk-Dove balance in Figure 1 shows that during 1963-1965 the FOMC was strongly divided between hawks and doves, and later it moved to a dovish majority. The dovish FOMC majority I identify in real time for this period explains why it might have been hard for Chairman Martin (perceived to be in the hawkish minority)

\footnotetext{
${ }^{31}$ Meltzer (2005), pg. 159: "The Federal Reserve did very little during the first half of 1965. [...] Martin wanted the FOMC to reach a consensus before it acted. He often waited, thinking that discussion, events, and perhaps collegiality would help form the consensus. But Governors Mitchell and Robertson persistently opposed tighter policy. On April 30, Sherman Maisel, an economics professor from the University of California at Berkeley, joined the Board, replacing a banker, Abbot Mills. Maisel usually voted with Mitchell and Robertson. Later, after the President appointed Andrew Brimmer to replace Canby Balderston, Martin was never certain when he would have a majority of the seven Board members. He hesitated to act with a majority of the FOMC if it did not include a majority of the Board."
} 
to reach a consensus and take prompt actions. Many of Meltzer's arguments and anecdotes are based on the readings of the FOMC transcripts, not available to public in real time. The Hawk-Dove balance shows that a dovish majority is indeed perceived in real time.

Contrary, during the 1970s the FOMC is perceived to have had a hawkish majority (about 60 to 70 percent) what might be surprising ex-post, given the outcome of the Great Inflation. However, this is not puzzling in light of the hypothesis that bad inflation outcomes of the 1970s reflect mistakes of well-meaning, optimally behaving central bankers, given what they knew about the economy in real time as discussed in Orphanides (2000); DeLong (1997); Romer and Romer (2002); Primiceri (2006), among others. ${ }^{32}$ However, I also find that about half of the hawkish FOMC during 1970 to 1974 was composed of members perceived as doves during the 1960s, thus swingers. ${ }^{33}$ This might explain why the inflation-unemployment trade-off were still perceived costly in this period. ${ }^{34}$

During 1970s the highest levels of persistent hawks are perceived from 1976 to 1978 (between 60 to 70 percent of the FOMC), under Burns and Miller as chairmen. Paul Volcker became the chairman of a hawkish FOMC. He was already part of it since 1975, in the position of the president of the Federal Reserve Bank of New York as a permanent voter, thus no difference in the overall composition of the FOMC preferences with his new position. An important difference though lies in the type of the chairman of the FOMC. During 1970s, the FOMC was chaired from a perceived hawk (Burns), a dove for less than two years (Miller) and again from a hawk (Volcker). ${ }^{35}$ The overall perception of the FOMC as hawkish during the 1970's

\footnotetext{
${ }^{32}$ The policymakers' misperceptions about the state of the economy (like potential output gap, natural rate of employment and the persistence of inflation) hypothesis of Great Inflation.

${ }^{33}$ Meltzer (2005) quotes "He [Burns] took over a Board most of whose members had been appointed by Presidents Kennedy and Johnson. To varying degrees, a majority preferred to continue inflation rather than increase unemployment. If inflation could be reduced at an unemployment rate of 4.25 or 4.50 percent, they would accept it. But they did not want any higher unemployment rate. There was a minority that wanted more restrictive policy and more action against inflation. [...] They gained support when inflation rose, but only until unemployment rose above the level the majority would accept."

${ }^{34}$ For instance, Primiceri (2006) argues that the underestimation of the natural rate of unemployment and the persistence of inflation in the Phillips curve result in over-expansionary policies and higher inflation. Furthermore, when policymakers start reacting to inflation, pushing unemployment above the perceived (low) natural rate does not seem to reduce inflation. They temporarily and mistakenly perceive a very costly inflation-unemployment trade-off, which explains why antiinflationary policy is postponed even further. The disinflation occurs only when the perceived inflation-unemployment trade-off becomes favorable, relative to the level of inflation.

${ }^{35}$ Some theories of the Great Inflation adopt an exogenous shift in the preferences of policymakers to explain the sharp disinflation and the low level of inflation since the early 1980s. Primiceri (2006) offers an explanation of the Volcker disinflation which is not based on a sudden change of policymakers' preferences in the late 1970s.
} 
suggests that the Federal Reserve during those years worried about inflation and spoke forcefully against it in public. The problem was that the FOMC (a majority of it, Burns included) believed that monetary policy is ineffective to deal with that type of inflation, what Romer and Romer (2013) refer to as the most dangerous idea in the Federal Reserve's monetary policy history. Instead, the FOMC and Burns especially suggested and supported government actions, like price and wage controls to fight inflation.

It is also interesting to see that the hawkish balance appears in decline during Paul Volcker's years as the Federal Reserve chair. This shift is due to the Board's composition, which was perceived to have a dovish bias during the years that are considered as Volcker's disinflation years. This goes pretty well in line with narratives that President Ronald Reagan administration was not happy with the tight policies of the Fed under Volcker. In response, President Reagan filled the Board with members whose policy preferences would counteract those of Volcker. During Volcker's tenure, President Reagan filled six Board seats. All these Board members were perceived by markets to have a dovish bias, i.e., Preston Martin, Martha Seger, Wayne D. Angell, Manuel H. Johnson, H. Robert Heller and Edward W. Kelley. Later on, both Wayne D. Angell and Edward W. Kelley revealed a more hawkish bias.

In the 1990s one observes a hawkish bias growing again. In these years the FOMC started discussing inflation targets as important to reach monetary policy objectives. Several FOMC members very often spoke publicly about "removing inflation from the equation". Later, implicitly a consensus built around the 2 percent target. ${ }^{36}$ Further, in the 2000s a rise of the dovish bias is perceived. Late 1990s and early 2000s correspond with a general acceptance of Greenspan's idea that due to productivity growth, the economy can grow faster, without exacerbating inflation. During these years a dovish stance is perceived for the majority of the FOMC, including Greenspan.

\subsection{Perceived Hawks/Doves and Dissents}

Literature has used dissents as a proxy of true preferences. However, as already discussed in the literature, the information content of individual votes and dissents is rather limited with respect to diversity, especially for committees that favor consensus, like the FOMC. For instance, Meade (2005) found that during the Greenspan's

\footnotetext{
${ }^{36}$ During an FOMC meeting in July 1996, Chairman Greenspan is quoted saying "Since we have all agreed on an implicit target around 2 percent, my question is, what percent?" (FOMC transcripts, July 2-3, 1996, p.63).
} 
time as chairman dissents accounted for only 7.5 percent of the votes, while the internal disagreement was estimated to be around 30 percent. Therefore internal disagreement does not always show up in a dissent.

How do the perceived preferences of the FOMC line up with dissents? For this comparison exercise, for each FOMC member, the vote (assent, dissent for tight, or dissent for ease) in a meeting $m$ is matched with the perceived preference of that member (hawk, dove or unknown). The perceived policy preference is based on information prior to the meeting $m$. Thus, information on votes of meeting $m$ does not inform the perceived preference of meeting $m$.

Since 1960 until the first FOMC meeting of 2015 there have been 436 dissents on policy: 272 for tighter policy and 164 dissents for ease. These dissents correspond only to scheduled meetings, excluding conference calls. Additional dissents not related with the direction of policy are abstracted from the analysis. Table 4 shows the distribution of dissents for ease or tight, conditional on the perceived preference of the dissenter. We observe a very good match of ex-ante perceptions with voting outcomes; dissents for tighter policy are predominantly cast from perceived hawks (about 86 percent of them) and dissents for ease are cast from perceived doves (about 79 percent). Also, perceived hawks seem to be the biggest dissenters but this is also related with the sample dominated by perceived hawks.

Table 4: Share of dissents for ease or tight, conditional on perceived preferences

\begin{tabular}{lcccc}
\hline \hline & Perceived Hawk & Perceived Dove & Unknown & Total \\
\hline Dissent for tight(er) & $86.2 \%$ & $6.6 \%$ & $7.0 \%$ & 272 \\
& & & & \\
Dissent for ease(ier) & $11.6 \%$ & $79.3 \%$ & $9.1 \%$ & 164 \\
\hline \hline
\end{tabular}

Results show that there is a good match of Hawk and Dove perceptions with dissents. However, dissents are very rare (only 7 percent of the total votes even during period 1960-2015) and they are casted by few members. About 40 percent of members in my sample have never dissented, and only 37 percent of total members have dissented at least twice (many of these dissents have been in opposite direction). As such dissents do not allow to identify a type, that is why usually the literature has discussed about preferences at a group level based on different characteristics (education, profession, position in the FOMC and so on). The hawk-dove preference measure is based on a larger set of information set (votes included, whenever discussed in public), therefore being able to assign a unique policy preference to the majority of FOMC members under investigation (93 percent of the 130 FOMC members in our sample), what is missing in existing studies. 


\subsection{Perceived Hawks/Doves and preferred interest rate}

Another proxy for individual preferences that has been used in the literature is the preferred interest rate measure of Chappell et al. (2005). To build this measure, they use transcripts and summaries of deliberations contained in the committee's Memoranda of Discussion and FOMC Transcripts. Information on the preferred rate of an FOMC member is usually revealed during the part of the FOMC meeting when alternatives for monetary policy are discussed, before a voting decision is taken. Chappell et al. (2005) constructed the dataset describing individual committee members' policy preferences, in terms of preferred interest rates, for the period 1970-1978 and 1987-1996.

In the following I compare, how perceptions hawk or dove for each member match with their preferred rates. For the comparison exercise I proceed as follows. First, using the dataset of Chappell et al. (2005), for each FOMC meeting, $m$, in time $t$, I compare the estimated preferred interest rate of each voting member $i, r_{t, m}^{i}$, with the chosen target rate, $r_{t, m}$. If the difference between the preferred rate, $r_{t, m}^{i}$, and the target rate, $r_{t, m}$, is equal to, or higher (lower) to a certain threshold, I denote this as a hawkish (dovish) preferred rate (see specification 1 ). I choose the threshold to be 0.25 percentage points as usually FOMC members express their preferences either in terms of alternatives proposed in the Bluebook or in 25- or 50-basis point movements relative to the prevailing funds rate (Chappell et al. (2005)). Next, I compare hawkish (dovish) preferred rates with the perceived policy preference of each member (hawk, dove or unknown), for the same meeting. Hawk and dove perceptions are based on information prior to this meeting.

$$
\text { Preferred } \text { rate }_{t, m}=\left\{\begin{array}{cc}
\text { dovish if } & r_{t, m}^{i}-r_{t, m} \leq-0.25 \\
\text { hawkish if } & r_{t, m}^{i}-r_{t, m} \geq 0.25
\end{array}\right.
$$

Results of this comparison are shown in Table 5. During the period 1970-1978, there have been 99 scheduled meetings and (unique) 38 FOMC members. In these meetings, out of 1151 preferred interest rates in total, only 27 percent of them exceeded the thresholds, meaning that majority of members seem to have preferred the rate that was decided. During 1987-1996, there were 76 scheduled meetings and (unique) 36 FOMC members. In these meetings, out of 846 preferred interest rates only 11 percent of them exceed the thresholds, meaning that preferred rates were even more uniform than in the previous sample. Interestingly, there rates show a higher disagreement before the voting process than what dissents show.

The match between preferred rates and perceived hawks and doves is good: the majority of hawkish (dovish) preferred rates belong to perceived hawks (doves). 
Table 5: Comparison of perceived preferences with preferred interest rates

\begin{tabular}{lcccc}
\hline \hline & Perceived Hawk & Perceived Dove & Unknown & Total \\
\hline 1970-1978 & & & & \\
Hawkish preferred rate & $67 \%$ & $23 \%$ & $10 \%$ & 163 \\
Dovish preferred rate & $33 \%$ & $55 \%$ & $12 \%$ & 150 \\
\hline $1987-1996$ & & & & \\
Hawkish preferred rate & $77 \%$ & $15 \%$ & $8 \%$ & 61 \\
Dovish preferred rate & $9 \%$ & $91 \%$ & $0 \%$ & 32 \\
\hline \hline
\end{tabular}

The match is remarkable especially for the second period where about 77 percent of hawkish preferred rates belong to the perceived hawks and 91 percent of dovish preferred rates belong to perceived doves. As discussed before, during 1970s there was a swing wave on the hawkish side (some dovish members of the 1960s turned hawk during 1970s). Guessing the correct timing of the swing in real time is difficult, what might explain the lower match in this period.

\subsection{Perceived Hawks/Doves and FOMC forecasts}

In the following I investigate how hawk and dove perceptions match with individual projections of the FOMC members. Since 1979, the FOMC prepares forecasts of GDP growth, inflation and unemployment, twice a year, in February and July. Forecasts in February are for current year, in July for current and next year. These forecasts are contained in the Monetary Policy Report (MPR) submitted to Congress as required by the Humphrey-Hawkins Full Employment and Balanced Growth Act. The MPR reported no names, only min, max and the central tendency of the individual forecasts. Individual FOMC member forecasts with names are available from 1992, known as the Romer (2010) dataset (updated until 2001). ${ }^{37}$ I updated this dataset up to 2007, as the individual projections are made available to the public with a lag of 10 years.

FOMC forecasting process goes as follows: All members (including non-voters) prepare their forecasts prior to the FOMC meeting preceding the MPR. In preparing these forecasts, all have access to the same staff forecasts (prepared for the FOMC meeting). In preparing their individual forecasts, no specific assumptions are given to FOMC members: forecasts are conditional on individual judgments of "appropriate" policy. At the FOMC meeting, the forecast of the staff and a summary

\footnotetext{
${ }^{37} \mathrm{~A}$ detailed data set of FOMC members' forecasts with member names attributed is compiled and described in Romer (2010).
} 
of members' forecasts are presented. After the FOMC meeting, members have the opportunity to revise their forecasts. The published data are supposed to be the final forecasts. These individual projections are currently posted on the Philadelphia Fed's web page. The projections do not include those of the Chairman because there is no record of those projections.

Figure 3: The Hawk-Dove gap in forecasts (current and next year), 1992-2007

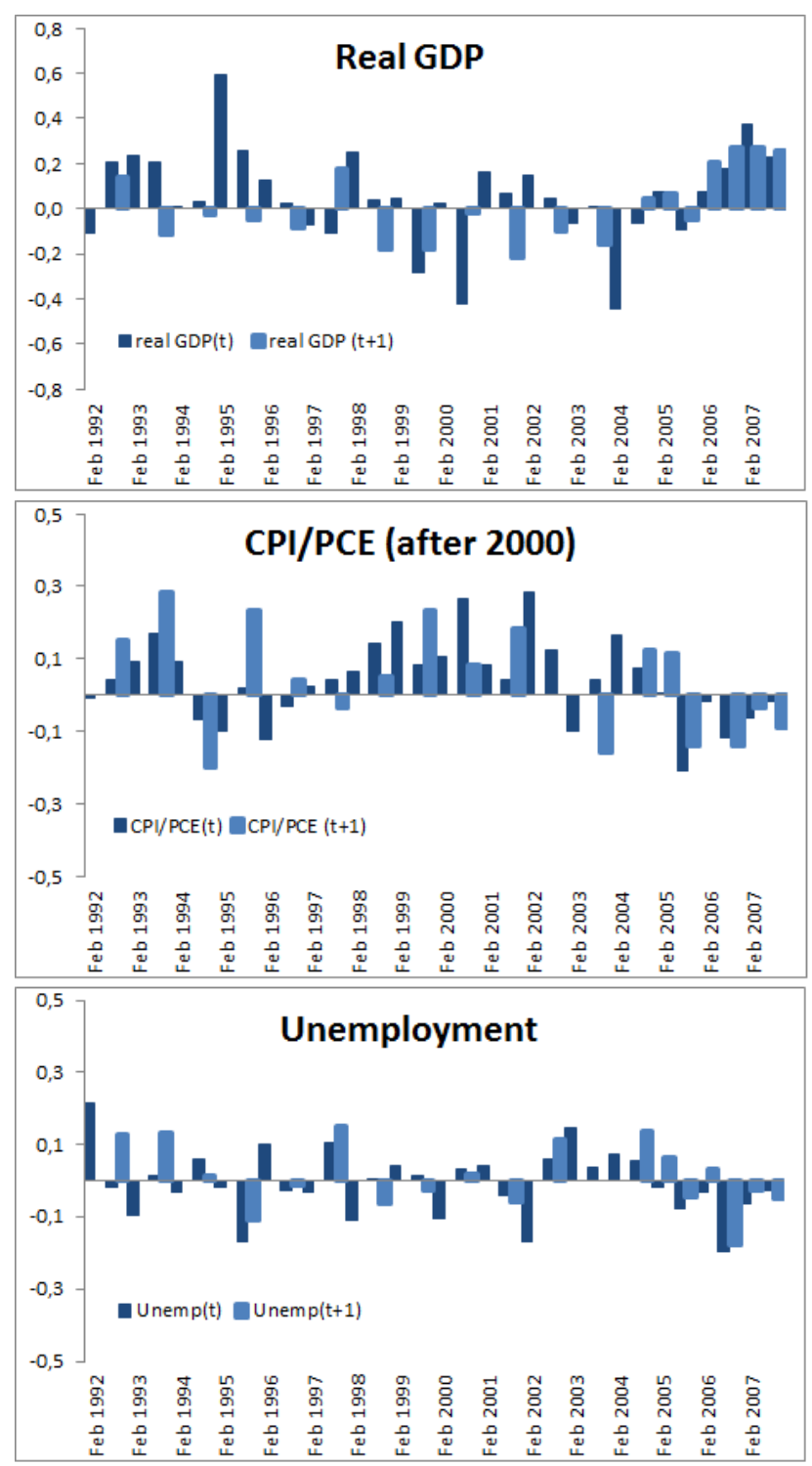

Notes: In 2000, FOMC members switched from forecasting CPI inflation to PCE (Personal Consumption Expenditure) inflation.

For the comparison I calculate for each forecast meeting, the average forecast of hawks (doves) for the real GDP growth, inflation rate and the unemployment rate, for the current and the next year. Figure 3 shows that there is a bias in forecasts of inflation from hawks for most of the sample, giving some justification to popular 
beliefs that hawks tend to see inflation around the corner. Important here is to recall that these forecasts are conditional on individual judgments of "appropriate" policy. Assuming that hawks tend to prefer higher rates (in line with the results from preferred rates) it is interesting to notice that they tend to forecast higher inflation on average even with higher preferred rates. This could be a strategic forecast rather than their 'best' forecast.

Another caveat here is that this sample period is made up of swingers, and few of these hawks and doves were perceived as persistent ones over their tenure at the FOMC. To account for this fact, in a second exercise, I compare the average forecast of persistent hawks, persistent doves and swingers, over the period 19922007. Results are shown in Table 6 .

Table 6: FOMC forecasts conditional on the type (1992-2007)

\begin{tabular}{|c|c|c|c|c|c|c|}
\hline \multirow[b]{2}{*}{ Variable } & \multicolumn{3}{|c|}{ Current Year } & \multicolumn{3}{|c|}{ Next Year } \\
\hline & Hawk & Dove & Swinger & Hawk & Dove & Swinger \\
\hline \multicolumn{7}{|l|}{ real GDP } \\
\hline Mean & 3,04 & 3,04 & 2,94 & 3,08 & 3,11 & 2,97 \\
\hline $\mathrm{SD}$ & $(0,76)$ & $(0,85)$ & $(0,79)$ & $(0,58)$ & $(0,70)$ & $(0,63)$ \\
\hline \multicolumn{7}{|l|}{ Inflation } \\
\hline Mean & 2,32 & 2,09 & 2,37 & 2,22 & 2,09 & 2,38 \\
\hline $\mathrm{SD}$ & $(0,62)$ & $(0,66)$ & $(0,65)$ & $(0,59)$ & $(0,58)$ & $(0,66)$ \\
\hline \multicolumn{7}{|c|}{ Unemployment } \\
\hline Mean & 5,39 & 5,35 & 5,47 & 5,22 & 5,23 & 5,32 \\
\hline $\mathrm{SD}$ & $(0,92)$ & $(0,74)$ & $(0,89)$ & $(0,77)$ & $(0,60)$ & $(0,73)$ \\
\hline Observations & 192 & 79 & 267 & 118 & 49 & 153 \\
\hline
\end{tabular}

Do persistent hawks tend to see inflation around the corner? They do in comparison to doves. Results show that persistent hawks forecast on average higher inflation than doves, slightly above the FOMC's 2 percent target and doves at the target. The difference is statistically significant $(p$-value $=0,000)$ but not as big in economic terms. However, one should keep in mind that inflation was very stable during 1992-2007. Interestingly, when compared to persistent hawks and doves, swingers forecast lower growth, higher inflation and higher unemployment.

\section{Conclusion}

I propose a novel measure of perceived policy preferences for Federal Open Market Committee members for the period 1960-2015. I show that during this period perceived preferences of the FOMC varied substantially. Their evolution features slow- and fast-switching regimes, both on the hawkish and dovish side. Moreover, I show that hawk and dove perceptions capture well "true" tendencies as expressed 
in FOMC transcripts with respect to the preferred rates, to FOMC dissents and FOMC forecasts.

This unique data set can be used for several research purposes. Foremost, this measure can prove helpful to investigate questions that relate to market perceptions on who is in majority, the hawks, the doves or a balance, with market expectations on future path of monetary policy or inflation expectations. Perceptions on the balances within the FOMC might prove especially important in cases when the economic data do not suggest a clear direction. With regard to monetary policy uncertainty, using this database, one can construct a measure that represents uncertainty over who will be the policy maker. The rotation scheme of Fed presidents every year brings exogenous variation in the combination of the FOMC policy preferences that can be exploited for identification. When used for these purposes, Hawk and Dove should be corrected for the state of the economy as known in real time. In addition, a higher weight to the preference of the Fed Chair could be more appropriate, given the role of the Fed chair as an agenda setter and consensus builder. 


\section{References}

Abrams, B. A., 2006. How richard nixon pressured arthur burns: Evidence from the nixon tapes. Journal of Economic Perspectives 20 (4), 177-188.

URL http://www. aeaweb.org/articles?id=10.1257/jep.20.4.177

Alt, J., Woolley, 1982. Reaction functions, optimization, and politics: Modelling the political economy of macroeconomic policy. American Journal of Political Science 26 (4), $707-740$.

Backus, D., Driffill, J., 1985. Inflation and reputation. The American Economic Review $75(3), 530-538$.

Barro, R., 1986. Reputation in a model of monetary policy with incomplete information. Journal of Monetary Economics 17 (1), 3 - 20.

Belden, S., 1989. Policy preferences of fomc members as revealed by disenting votes. Journal of Money, Credit and Banking 21, 432-441.

Blinder, A., Reis, R., 2005. Understanding the greenspan standard. Proceedings - Economic Policy Symposium - Jackson Hole (Aug), 11-96.

URL https://EconPapers.repec.org/RePEc:fip:fedkpr:y:2005:i :aug:p:11-96

Bordo, M. D., Istrefi, K., 2018. The perceived fomc: The making of hawks, doves and swingers. In: Eijffinger, S., Masciandaro, D. (Eds.), Hawks and Doves: Deeds and Words - Economics and Politics of Monetary Policymaking. CEPR Press, London, Ch. 5, pp. $41-61$.

Chappell, H. W., McGregor, R. R., Vermilyea, T., 2005. In: Committee Decisions on Monetary Policy. Cambridge: MIT Press.

DeLong, B. J., 1997. America's only peacetime inflation: The 1970s. Chicago, IL: University of Chicago Press.

Ehrmann, M., Fratzscher, M., October 2013. Dispersed communication by central bank committees and the predictability of monetary policy decisions. Public Choice 157 (1), 223-244.

Hamilton, J. D., Pruitt, S., Borger, S., July 2011. Estimating the market-perceived monetary policy rule. American Economic Journal: Macroeconomics 3 (3), 1-28.

URL http://www . aeaweb.org/articles?id=10.1257/mac.3.3.1

Hansen, S., McMahon, M., 2016. First impressions matter: Signalling as a source of policy dynamics. The Review of Economic Studies 83 (4), 1645-1672.

Havrilesky, T. M., Gildea, J. A., 1989. The policy preferences of fomc members as revealed by dissenting votes: Comment. Journal of Money, Credit and Banking 23, 130-138.

Hetzel, R. L., 1998. Arthur Burns and inflation. Economic Quarterly (Win), 21-44. URL https://ideas.repec.org/a/fip/fedreq/y1998iwinp21-44.html

Levin, A., Wieland, V., Williams, J. C., 1999. Robustness of simple monetary policy rules under model uncertainty. In: Taylor, J. B. (Ed.), Monetary Policy Rules. Chicago: University of Chicago Press. 
Levin, A., Wieland, V., Williams, J. C., 2003. The performance of forecast-based monetary policy rules under model uncertainty. The American Economic Review 93(3), 622-645.

Meade, E., 2005. The FOMC: preferences, voting, and consensus. Federal Reserve Bank of St. Louis Review 87 (2), 93-101.

Meltzer, A. H., 2005. Origins of the great inflation. Federal Reserve Bank of St. Louis Review (March/April), 145-176.

Orphanides, A., 2000. The quest for prosperity without inflation. Working Paper 15, European Central Bank.

Owyang, M., Ramey, G., 2004. Regime switching and monetary policy measurement,. Journal of Monetary Economics 51 (8), 1577-1597.

Primiceri, G., 2006. Why inflation rose and fell: Policymakers' beliefs and US postwar stabilization policy. The Quarterly Journal of Economics (121), 867-901.

Riboni, A., Ruge-Murcia, F., 2014. Dissent in monetary policy decisions. Journal of Monetary Economics 66 (C), 137-154.

Riboni, A., Ruge-Murcia, F. J., 2010. Monetary policy by committee: Consensus, chairman dominance, or simple majority? The Quarterly Journal of Economics 125 (1), 363-416.

Richard Clarida, J. G., Gertler, M., 2000. Monetary policy rules and macroeconomic stability: Evidence and some theory. The Quarterly Journal of Economics 115 (1), 147-180.

Romer, C., Romer, D., 2002. The evolution of economic understanding and postwar stabilization policy. In: Rethinking Stabilization Policy. Federal Reserve Bank of Kansas City, pp. 11-78.

Romer, C. D., Romer, D. H., March 2004. Choosing the federal reserve chair: Lessons from history. Journal of Economic Perspectives 18 (1), 129-162.

Romer, C. D., Romer, D. H., May 2013. The most dangerous idea in federal reserve history: Monetary policy doesn't matter. American Economic Review 103 (3), 55-60.

Romer, D., 2010. A new data set on monetary policy: The economic forecasts of individual members of the fomc. Journal of Money, Credit and Banking 42 (5), 951-957.

Sibert, A., 2003. Monetary policy committees: Individual and collective reputations. The Review of Economic Studies 70 (3), 649-665.

Taylor, J. B., 1993. In: Discretion versus policy rules in practice. Vol. 31(1) of CarnegieRochester Conference Series on Public Policy. Elsevier, pp. 195-214. 


\section{A Perceptions about the policy preference of Fed Chairs, 1990-2015}

This section presents selected discussion relating to expected policy preferences for Arthur Burns, G. William Miller and Alan Greenspan when they were nominated as the Federal Reserve chair. ${ }^{38}$ For Paul Volcker, Ben Bernanke and Janet Yellen these expectations correspond to their first stints in the FOMC, that did not correspond with the position of the Federal Reserve chair. Initially, Paul Volcker was the president of the Federal Reserve of New York (1995-1979) and Janet Yellen and Ben Bernanke were Board members, in 1994-1997 and 2002-2005, respectively. The identification of preferences for the rest of the FOMC members follows the same logic.

William McChesney Martin. Martin is the longest-serving chairman of the Federal Reserve, serving from 1951 to 1970. My sample covers his last ten years (1960-1970), e period through which he is always perceived as a hawk. For instance, in 1957 the press writes that Martin "lists himself as a Democrat, but his associations have often been with Republicans of the conservative school" ${ }^{39}$, in 1965 that he "tends toward a harder money policy"40 and in 1966 that "inflation is his concern". ${ }^{41}$ In 1968 the press further writes that Martin's critics complain that "he is far too worried about inflation and not concerned enough with full employment and economic growth". ${ }^{42}$ Also he is often cited as being a 'problem' or an 'impediment' for either President Kennedy's or President Johnson's policies, and as siding with the conservative arm of the Board and of the FOMC.

Arthur Burns. In 1969, President Nixon nominated Arthur Burns as the future Federal Reserve chairman following William McChesney Martin who lead the Federal Reserve for almost 20 years. At the time of the nomination, the press cited widely several previous speeches of Burns indicating that he considers inflation as the nation's number 1 economic problem. In this regard, market participants viewed his nomination as a reassurance in fighting inflation. ${ }^{43}$ Burns was considered a conservative economist, expected to continue Martin's philosophy and such, under him "the federal reserve is more likely to overstay restraint than to ease too soon and too much". ${ }^{44}$ Based on many similar articles during this period, Burns is assigned

\footnotetext{
${ }^{38}$ William McChesney Martin became the chairman of the Federal Reserve in 1951, a period not covered in my sample.

${ }^{39}$ Martin and Money: Fed's Urbane Boss Sits in the Eye of a Political Hurricane, Wall Street Journal, 4 March 1957.

${ }^{40}$ Robertson Shakes Some of the Reserve Out of Federal Reserve Board, Los Angeles Times, 26 September 1965 .

${ }^{41}$ Martin: Inflation Is His Concern, Chicago Tribune, 10 January 1966.

${ }^{42}$ Martin Won't Quit as Federal Reserve Chief: Banking Official Once Said New President Should Be Free to Pick Own Man for Post, Los Angeles Times, 29 November 1968.

${ }^{43}$ In 1968 Burns' inflation fighting appetite is referred as follows: "A leading adviser to President'elect Nixon said today that inflation remains the nation's prime economic problem, and supported strict enforcement of anti-trust laws to combat price increases. He hinted at similar action to check wage spirals. Dr. Arthur F. Burns, who was chairman of the Presidential Council of Economic Advisers in the Eisenhower administration, backed a long-range program for small, yearly tax reductions." "Nixon Adviser Calls for Inflation Curbs", Chicago Tribune, November 11, 1968.

44 "Fed-restraint may last too long: Heller Ponders Policy of Chairmen", Chicago Tribune,
} 
a policy preference as an expected hawk.

G. William Miller. In 1978, President Carter's nomination of G. William Miller, a businessman, to succeed Arthur Burns took many by surprise, as nothing was known about him in terms of policy beliefs and preferences. However, even though his beliefs were pretty unknown, the press in this period highlights that Miller's appointment was greeted with more enthusiasm by economic liberals than by conservatives and that market analysts expect him to be "fairly liberal with monetary growth" and for "long term rates to increase on the theory that the new Chairman might not fight inflation as hard as Burns would". Based on these and other similar expectations, the policy preference of Miller is coded as expected dove. ${ }^{45}$

Paul Volcker. A year later, in 1979, President Jimmy Carter nominates Paul Volcker as the next Federal Reserve chair. By this time, Volcker's policy preferences as an inflation hawk were widely recognized, home and abroad. His first contact with the FOMC began in August 1975 as the president of the Federal Reserve Bank of New York. At the time of his nomination, the New York Times labeled him a 'monetary pragmatist'. He was seen 'philosophically sympathetic' with Fed Chairman Arthur Burns, meaning 'that he leans toward tight money policies and high interest rates to retard inflation'. Also in 1975, the press cites Volcker saying that he feels there is a tendency (of the Fed) to downplay inflation risks while overemphasizing the dangers of recession. ${ }^{46}$

Alan Greenspan. After eight years of Fed chairmanship of Volcker, in 1987 the press refers to President Ronald Reagan announcing that he will nominate conservative economist Alan Greenspan to replace him. Many press articles in this time refer to Greenspan as an avowed inflation-fighter like Paul Volcker. The expected hawk perception for Greenspan was confirmed for most of his term. The perception of Greenspan as a dove started to build in the second part of 1997 and it was maintained until 2005. These years correspond with Greenspan maintaining the line that the observed productivity trend in the 1990s had increased the potential for non-inflationary growth. ${ }^{47}$ Some other FOMC members had a similar swing in this period as well.

Ben Bernanke. Similarly, when George W. Bush nominated Ben Bernanke for the Board in 2002, market analysts expressed that his nomination would help main-

October 20, 1969.

45 "Jack Carlson, vice president and chief economist of the USA Chamber of Commerce, was less enthusiastic: "the departure of Chairman Arthur Burns will create uncertainty about nations's commitment to fight inflation. [...] the president has elected a person whose monetary policy positions are unknown." In Congress, Rep Henry Reuss, the generally liberal chairman of the House banking Comm, said: "Mr. Miller sounds great. His record on making jobs is simply excellent and I would like to see our monetary policy focus not just on a stable dollar but on stable jobs." "New Federal Reserve Chief Chosen", Los Angeles Times, 29 December 1977.

${ }^{46}$ Fed Promotes Some Gain in Money Supply: 5 to $7.5 \%$ Growth Rate, Los Angeles Times, 2 May 1975.

${ }^{47}$ Blinder and Reis (2005) discuss as well the 'dovish' case of Greenspan: "Of course, Greenspan's initial image was not that of an inflation 'dove'. In fact, he was typically portrayed by the media as an inflation 'hawk' in the early years of his chairmanship. It took the media almost a decade to catch on to the fact that, relative to the center of gravity of the FOMC, Greenspan was actually a dove - which became crystal clear when he repeatedly restrained a committee that was eager to raise rates in 1996-1997." 
tain the Federal Reserve's credibility for being tough on inflation. ${ }^{48}$ Market analysts expected that Bernanke will tend to the hawkish side of the policy spectrum. Furthermore, even though his political preferences were briefly mentioned (a Republican though not a very active one), Bernanke was not seen as a doctrinaire on monetary matters. ${ }^{49}$ The expectation of Bernanke as a hawk was reversed from the start of his FOMC stint, although his case has been more confusing for the market than for others. Bernanke's years as a Board Governor from 2002 to 2005, corresponded with deflation fears in the US. Being an advocate of inflation targeting, Bernanke spoke often about the importance of preventing deflation in this period. His reference to Milton Friedman's notion of a helicopter drop of money as a deflation-fighting tool earned him the "Helicopter Ben" nickname. Moreover, he was "widely seen as a deflation fighter and not an inflation warrior" ${ }^{50}$ and financial markets took his position on deflation to mean that "he is a "dove" - less committed to battling inflation - and that he would raise rates less than Mr. Greenspan might". ${ }^{51}$ Generally, Bernanke was considered on the moderate to the dovish side of the spectrum during his stint as a Board member and as the Federal Reserve chair.

Janet Yellen. Janet Yellen's first stint on the FOMC began in 1994 as a Board member. When president Clinton nominated her and Alan Blinder for the Board, the New York Times noted that their "philosophies suggest that they may seek to temper the pace at which the nation's central bank raises interest rates to fight inflation". ${ }^{52}$ Furthermore, the press noted that with the two new nominations, the balance of power within the Fed is seen as shifting toward the 'inflation doves'. As a result, 'growth-oriented' policies were expected to become more pronounced. ${ }^{53}$

\footnotetext{
${ }^{48}$ Bush announces intention to nominate two economists to Federal Reserve Board, $B N A$ 's Banking Report, 13 May 2002.

${ }^{49}$ Bush to Announce Nominations to Federal Reserve Board, Dow Jones Business News, May 2002.

50 "FXAnalytics Focus: Drum Roll...The Next Fed Chairman", Dow Jones Capital Markets Report, 19 October2005.

${ }^{51}$ What the New Fed Chief Means to You, The Wall Street Journal, October 302005.

${ }^{52} 2$ Economists Nominated to Fed, The New York Times, 23 April 1994.

${ }^{53}$ Monetary Credentials Still in Doubt, Financial Times, 25 April 1994.
} 